\title{
PELAKSANAAN EDUKASI PENGENDALIAN GULA DARAH \\ PASIEN DIABETES MELITUS TIPE 2 DI RUMAH SAKIT \\ PANTI RAPIH YOGYAKARTA
}

\author{
Maria Meilina Ekasari ${ }^{1}$, Ana Setiyorini ${ }^{2}$ \\ ${ }^{1}$ Rumah Sakit Panti Rapih, meilina.ekasari1@gmail.com \\ ${ }^{2}$ STIKes Panti Rapih Yogyakarta, setiyorini.ana@gmail.com
}

\begin{abstract}
ABSTRAK
Latar Belakang: Diabetes Mellitus (DM) merupakan penyakit gangguan metabolik terutama metabolisme karbohidrat yang disebabkan oleh berkurangnya atau ketiadaan hormon insulin dari sel beta pankreas, atau akibat gangguan fungsi insulin, atau keduanya. DM jika tidak dikelola dengan baik dapat mengakibatkan berbagai penyakit menahun. Edukasi pada pasien DM tipe 2 di Rawat Jalan Rumah Sakit Panti Rapih sudah dilaksanakan oleh perawat, ahli gizi maupun dokter, tetapi pelaksanaannya belum optimal.
\end{abstract}

Tujuan: Mendapatkan gambaran tentang pelaksanaan edukasi terhadap gula darah pada pasien DM tipe 2 oleh perawat dari fase prainteraksi sampai fase terminasi di Rawat Jalan Rumah Sakit Panti Rapih Yogyakarta.

Metode: penelitian deskripsi kuantitatif dengan menggunakan survey kepada perawat pemberi edukasi yang dilakukan pada Bulan Maret-Mei 2019. Jumlah sampel 30 dengan teknik acidental sampling. Sampel yang digunakan adalah perawat yang melakukan edukasi pasien DM tipe 2 di Rawat Jalan Rumah Sakit Panti Rapih. Analisa dilakukan dengan cara univariabel mengggunakan distribusi frekuensi dan persentase.

Hasil: Pelaksanaan edukasi sebagian besar atau sebanyak 25 responden (83\%) dalam kriteria baik, sebagian kecil atau 5 responden (17\%) dalam kriteria cukup, dan tidak ada atau 0 responden $(0 \%)$ dalam kriteria kurang dalam melaksanakan prosedur edukasi terhadap pengendalian gula darah pada pasien DM tipe 2 dari fase prainteraksi sampai fase terminasi.

Simpulan: Perawat perlu meningkatkan kemampuan perawat dalam melakukan pendidikan kesehatan pada pasien dengan menggunakan standar operasional prosedur dan melakukan peninjauan kembali standar operasional prosedur.

Kata kunci: DM type 2, pendidikan kesehatan, kontrol gula darah 
Pelaksanaan Edukasi Pengendalian Gula Darah Pasien Diabetes Melitus Tipe 2 di Rumah Sakit Panti Rapih Yogyakarta

\begin{abstract}
Background: Diabetes Mellitus (DM) is a metabolic disorder caused by a reduction or absence of the insulin hormone from pancreatic beta cells, or due to impaired insulin function, or both. If the DM not managed properly can lead several of chronic disease. The education program for type $2 \mathrm{DM}$ patients had been done by nurses, dietitians and doctors in outpatient department, but the quality of implementation has not been discovered.

Objective: To describe the implementation of the blood glucose control health education program in patients with type 2 diabetes mellitus from the preinteraction phase to the termination phase at outpatient department in a private hospital Yogyakarta.

Methods: An observational quantitative research conducted from March to May 2019 in outpatient department in a private hospital Yogyakarta. Thirty respondents were recruit with accidental sampling technique. The inclusion criteria was nurses who provide health education to patients with type $2 \mathrm{DM}$. The observation performed during the health education session. Univariate analysis used to analysis the data. The distribution of data presented in frequency and percentage.

Results: The majority of respondents $(n=25 ; 83 \%)$ performed well, a small proportion of respondent $(n=5 ; 17 \%)$ performed pretty good when deliver the blood sugar control health education in patients with type 2 DM from the preinteraction phase to the termination phase.

Conclusion: It is necessary to improve the ability of nurses in conducting health education in patients by using standard operating procedures and conducting review of operational standard procedures.
\end{abstract}

Keywords: type 2 DM, health education, blood glucose control

\title{
PENDAHULUAN
}

Latar Belakang

Diabetes Mellitus (DM) merupakan penyakit gangguan metabolik terutama metabolisme karbohidrat yang disebabkan oleh berkurangnya atau ketiadaan hormon insulin dari sel beta pankreas, atau akibat gangguan fungsi insulin, atau keduanya (Sutedjo, 2010). DM jika tidak dikelola dengan baik dapat mengakibatkan berbagai penyakit penyulit menahun, seperti penyakit serebro vasculer, penyakit jantung koroner, penyakit pembuluh darah 
tungkai, penyulit pada mata, ginjal dan syaraf. Jika kadar glukosa darah dapat selalu dikendalikan dengan baik, diharapkan semua penyulit menahun tersebut dapat dicegah, paling tidak sedikit dihambat (Soegondo, dkk, 2013). Di Indonesia menurut survei yang dilakukan WHO 2016, Indonesia menempati urutan ke-4 dengan jumlah penderita diabetes terbesar setelah India, Cina, dan Amerika Serikat, dengan prevalensi $8,4 \%$ dari total penduduk. Prevalensi Diabetes Mellitus di Daerah Istimewa Yogyakarta adalah 2,4\% dari jumlah penduduk semua umur (Infodatin, 2018). Kejadian DM di Indonesia lebih banyak ditemukan di perkotaan daripada di desa (Sutedjo, 2010). Menurut data rekam medis tahun 2018 di Rumah Sakit Panti Rapih, kunjungan pasien DM tipe 2 di Rawat Jalan pada tahun 2018 sejumlah 18.458 dengan rincian laki-laki: 9.073, perempuan: 9.385, dan yang meninggal ada 52 orang. Pada Bulan Januari-Februari 2019, jumlah kunjungan ada 2.943 dengan rincian laki-aki: 1.529, perempuan 1.414 .
Edukasi pada pasien DM tipe 2 di Rawat Jalan Rumah Sakit Panti Rapih sudah dilaksanakan oleh petugas kesehatan baik perawat, ahli gizi, maupun dokter, tetapi pelaksanaan pendidikan kesehatan belum optimal. Pendidikan kesehatan di rawat jalan dilakukan oleh seluruh perawat yang bertugas ketika pasien melakukan periksa. Edukasi pada pasien DM di rawat jalan merupakan program rumah sakit yang harus diberikan. Penelitian ini sangat penting untuk dilakukan mengingat penyakit Diabetes Melitus tidak dapat disembuhkan, namun dapat dikontrol. Pasien DM tipe 2 harus menjaga pola hidupnya dengan baik sehingga diperlukan edukasi bagi mereka. Perawat perlu melakukan edukasi yang terencana, menggunakan tahapan yang jelas yaitu dari fase prainteraksi, fase orientasi, fase kerja, dan fase terminasi agar pasien mampu mengendalikan dan mengontrol gula darah dalam kehidupan sehari-hari. 
Pelaksanaan Edukasi Pengendalian Gula Darah Pasien Diabetes Melitus Tipe 2 di Rumah Sakit Panti Rapih Yogyakarta

\section{Rumusan Masalah}

Bagaimana pelaksanaan edukasi terhadap pengendalian gula darah pada pasien Diabetes Mellitus tipe 2 oleh perawat di Rawat Jalan Rumah Sakit Panti Rapih Yogyakarta?

\section{Tujuan Penelitian}

1. Tujuan Umum

Mendapatkan gambaran tentang pelaksanaan edukasi pengendalian gula darah pada pasien Diabetes Mellitus Tipe 2 di Rumah Sakit Panti Rapih Yogyakarta.

2. Tujuan Khusus

a. Mendapatkan gambaran tentang pelaksanaan edukasi pengendalian gula darah pada pasien Diabetes Mellitus Tipe 2 pada fase prainteraksi di Rumah Sakit Panti Rapih Yogyakarta.

b. Mendapatkan gambaran tentang pelaksanaan edukasi pengendalian gula darah pada pasien Diabetes Mellitus Tipe 2 pada fase orientasi di

\begin{abstract}
Rumah Sakit Panti Rapih Yogyakarta.

c. Mendapatkan gambaran tentang pelaksanaan edukasi pengendalian gula darah pada pasien Diabetes Mellitus Tipe 2 pada fase kerja di Rumah Sakit Panti Rapih Yogyakarta.

d. Mendapatkan gambaran tentang pelaksanaan edukasi pengendalian gula darah pada pasien Diabetes Mellitus Tipe 2 pada fase terminasi di Rumah Sakit Panti Rapih Yogyakarta.
\end{abstract}

\section{METODE PENELITIAN \\ Rancangan Penelitian}

Penelitian ini merupakan penelitian deskriptif kuantitatif dengan pendekatan survey.

\section{Variabel Penelitian}

Variabel penelitian ini adalah univariabel yaitu pelaksanaan edukasi pengendalian gula darah pada pasien Diabetes Mellitus tipe 2 di Rumah Sakit Panti Rapih Yogyakarta dengan sub variabel 
pelaksanaan edukasi pada fase prainteraksi, fase orientasi, fase kerja, dan fase terminasi.

\section{Populasi dan Sampel}

Populasi dari penelitan ini adalah seluruh perawat rawat jalan yang melakukan edukasi pada penderita Diabetes Mellitus tipe 2 di Rawat Jalan Rumah Sakit Panti Rapih Yogyakarta.

Sampel dalam penelitian ini diambil menggunakan teknik acidental sampling dengan cara observasi atau pengamatan pada perawat yang memberikan edukasi sebanyak 30 perawat.

\section{Teknik Pengumpulan Data dan Instrumen Pengumpulan Data}

Peneliti melakukan perijinan ke lokasi penelitian. Peneliti memilih responden sesuai dengan kriteria yaitu perawat yang melakukan edukasi pada pasien yang menderita DM tipe 2 dan melakukan pengambilan data yang didahului dengan penjelasan alasan melakukan penelitian kepada responden sesuai dengan etika penelitian. Data diambil setelah responden menyatakan setuju sebagai sumber data yang dibuktikan dengan menandatangani lembar persetujuan menjadi responden. Peneliti mengambil data dengan cara memberikan surat permohonan menjadi responden, lembar persetujuan menjadi responden dan kemudian melakukan observasi pelaksanaan edukasi yang dilakukan oleh perawat.

Instrumen penelitian dibuat oleh peneliti berdasarkan tujuan penelitian. Instrumen yang digunakan adalah pedoman observasi yang disusun oleh peneliti berdasarkan konsep prosedur memberikan penyuluhan mulai dari fase prainteraksi, fase orientasi, fase kerja, dan fase terminasi yang diukur dengan 24 item observasi dengan nilai 0 jika tidak dilakukan, nilai 1 jika dilakukan. Kriteria pelaksanaan edukasi diukur dengan pemberian edukasi dikatakan baik jika 17-24 item prosedur dilakukan, sedang jika 9-16 item prosedur dilakukan, dan kurang jika $0-8$ item prosedur dilakukan. 
Pelaksanaan Edukasi Pengendalian Gula Darah Pasien Diabetes Melitus Tipe 2 di Rumah Sakit Panti Rapih Yogyakarta

\section{Pengolahan Data dan Analisis} Data

Pengolahan data dilakukan dengan proses editing, coding, tabulating, dan scoring.

Analisis data dilakukan

secara kuantitatif dan disesuaikan dengan tujuan yang akan dicapai pada penelitian ini dengan distribusi frekuensi yang ditampilkan dalam bentuk narasi dan tabel. Data hasil penghitungan distribusi frekuensi dan hasil prosentase dari variabel disajikan dalam bentuk narasi dengan kategori 0\%: Tidak ada, 1-25\%: Sebagian kecil, 26-49\%: Kurang dari separo, 50\%: Separo, 51-75\%: Lebih dari separo, 76-99\%:

Sebagian besar, dan 100\%: Seluruhnya.

\section{Tempat dan Waktu Penelitian}

Penelitian ini dilakukan di Rumah Sakit Panti Rapih Yogyakarta pada Bulan Maret-Mei 2019.

\section{HASIL DAN PEMBAHASAN}

Penelitian tentang Pelaksanaan Edukasi Pengendalian Gula Darah pada Pasien Diabetes Mellitus Tipe 2 di Rumah Sakit Panti Rapih Yogyakarta merupakan penelitian deskriptif kuantitatif dengan pendekatan survey yang dilakukan di Rumah Sakit Panti Rapih Yogyakarta dengan menggunakan data primer. 
Tabel 1

Distribusi Frekuensi Hasil Observasi Pelaksanaan Edukasi Pengendalian Gula Darah pada Pasien Diabetes Mellitus Tipe 2 Berdasarkan Fase di Rumah Sakit Panti Rapih Yogyakarta

\begin{tabular}{|c|c|c|c|c|c|}
\hline \multirow[t]{2}{*}{ No. } & \multirow[t]{2}{*}{ Item Observasi } & \multicolumn{2}{|c|}{ Dilakukan } & \multicolumn{2}{|c|}{$\begin{array}{c}\text { Tidak } \\
\text { Dilakukan }\end{array}$} \\
\hline & & Jumlah & $\%$ & Jumlah & $\%$ \\
\hline \multirow[t]{3}{*}{1.} & Fase Prainteraksi & & & & \\
\hline & a. Mengecek catatan keperawatan pasien & 30 & 100 & 0 & 0 \\
\hline & b. Menyiapkan leaflet DM dari RS Panti Rapih & 30 & 100 & 0 & 0 \\
\hline \multirow[t]{6}{*}{2.} & Fase Orientasi & & & & \\
\hline & a. Identifikasi pasien (nama dan tanggal lahir) & 30 & 100 & 0 & 0 \\
\hline & b. Memberikan salam dan menyebutkan nama pasien & 28 & 93,3 & 2 & 6,7 \\
\hline & c. Memperkenalkan nama pasien. & 11 & 36,7 & 19 & 63,3 \\
\hline & $\begin{array}{l}\text { d. Menjelaskan tujuan tindakan penyuluhan yang akan } \\
\text { dilakukan }\end{array}$ & 17 & 56,7 & 13 & 43,3 \\
\hline & e. Menjelaskan peran perawat dan peran pasien & 22 & 73,3 & 8 & 26,7 \\
\hline \multirow[t]{10}{*}{3.} & Fase Kerja & & & & \\
\hline & a. Pastikan privacy pasien terjaga, ruangan tertutup & 30 & 100 & 0 & 0 \\
\hline & b. Mengkaji pasien & 30 & 100 & 0 & 0 \\
\hline & $\begin{array}{l}\text { c. Memberi kesempatan pasien untuk bertanya sebelum } \\
\text { tindakan }\end{array}$ & 19 & 63,3 & 11 & 36,7 \\
\hline & d. Mengukur tekanan darah, nadi, dan glucometri & 30 & 100 & 0 & 0 \\
\hline & e. Menginformasikan perubahan gaya hidup & 16 & 53,3 & 14 & 46,7 \\
\hline & f. Menjelaskan pengaturan makan/diet & 21 & 70 & 9 & 30 \\
\hline & g. Menganjurkan olah raga & 20 & 66,7 & 10 & 33,3 \\
\hline & h. Menganjurkan pengobatan rutin & 29 & 96,7 & 1 & 3,3 \\
\hline & i. Menganjurkan pemantauan mandiri & 26 & 86,7 & 4 & 13,3 \\
\hline \multirow[t]{9}{*}{4.} & Fase Terminasi & & & & \\
\hline & a. Membereskan alat-alat & 27 & 90 & 3 & 10 \\
\hline & b. Mencuci tangan & 27 & 90 & 3 & 10 \\
\hline & c. Mendokumentasikan tindakan keperawatan & 30 & 100 & 0 & 0 \\
\hline & d. Sikap perawat tanggap terhadap respon pasien & 30 & 100 & 0 & 0 \\
\hline & e. Sikap perawat yang teliti & 30 & 100 & 0 & 0 \\
\hline & f. Sikap perawat yang ramah & 30 & 100 & 0 & 0 \\
\hline & g. Sikap perawat yang sabar & 30 & 100 & 0 & 0 \\
\hline & h. Sikap perawat yang cekatan & 30 & 100 & 0 & 0 \\
\hline
\end{tabular}

Berdasarkan Tabel 1, hasil penelitian yang terdiri dari 30 responden, pada fase prainteraksi didapatkan sebanyak $100 \%$ atau seluruhnya responden telah mengecek catatan keperawatan dan menyiapkan leaflet. Hal ini sesuai dengan konsep komunikasi terapeutik yang disampaikan oleh Keliat (1996) bahwa pada fase prainteraksi ini perawat mengumpulkan data pasien untuk menemukan berbagai informasi 
Pelaksanaan Edukasi Pengendalian Gula Darah Pasien Diabetes Melitus Tipe 2 di Rumah Sakit Panti Rapih Yogyakarta

seperti kondisi maupun perkembangannya (Keliat, 1996).

Dari hasil penelitian yang terdiri dari 30 responden, pada fase orientasi didapatkan sebanyak $100 \%$ atau seluruh responden telah mengidentifikasi pasien. Hal ini sesuai teori bahwa yang harus dilakukan pada tahap orientasi adalah memperkenalkan diri, mengevaluasi kondisi pasien, dan menyepakati kontrak mengenai topik yang dibicarakan, tempat, waktu, dan tujuan (Keliat, 1996). Penulis dapat menyatakan bahwa pada fase orientasi sudah dilaksanakan oleh responden dengan baik. Sebanyak 93,3\% responden telah memberikan salam dan menyebut nama pasien. Hal ini sejalan dengan hasil penelitian Kusuma, (2013) yang mengatakan bahwa pada tahap ini bila perawat melakukan komunikasi terapeutik dengan baik dengan pasien maka disini penilaian terhadap pelayanan yang diberikan perawat dinilai baik. Dengan memberi salam dan menyebut nama pasien maka pasien merasa dihargai dan dikenal maka fase orientasi menjadi baik. Sebanyak 63,3\% atau lebih dari separuh perawat tidak memperkenalkan nama dalam memberikan edukasi pada fase orientasi.

Hal ini tidak sejalan dengan hasil penelitian Kusuma, (2013) yang mengatakan bahwa pada tahap orientasi bila perawat melakukan komunikasi terapeutik dengan baik dengan pasien maka di sini penilaian terhadap pelayanan yang diberikan perawat dinilai baik. Dalam edukasi dibutuhkan kepercayaan antara pasien dengan pemberi edukasi. Apabila pemberi edukasi tidak mengenalkan diri dalam hal nama, sangat dimungkinkan ada rasa ketidakpercayaan pasien terhadap perawat yang berdampak pada ketidakberhasilan edukasi. Sebanyak $56,7 \%$ atau lebih dari separo responden telah menjelaskan tujuan tindakan penyuluhan yang akan dilakukan. Hal ini sesuai teori bahwa yang harus dilakukan pada tahap orientasi adalah memperkenalkan diri, mengevaluasi kondisi pasien, dan menyepakati kontrak mengenai topik yang dibicarakan, tempat, waktu, dan tujuan (Keliat, 1996). Sebanyak 
$73,3 \%$ responden telah mejelaskan peran perawat dan peran pasien yang harus dilakukan. Hal ini sesuai teori bahwa yang harus dilakukan pada tahap orientasi adalah memperkenalkan diri, mengevaluasi kondisi pasien, dan menyepakati kontrak mengenai topik yang dibicarakan, tempat, waktu, dan tujuan (Keliat, 1996).

Dari hasil penelitian yang terdiri dari 30 responden, pada fase kerja didapatkan sebanyak $100 \%$ atau seluruh responden telah memastikan privacy pasien terjaga dan telah mengkaji pasien. Hal ini sesuai teori yang dikemukakan oleh Keliat, (1996) bahwa pada fase kerja perawat dapat memberikan edukasi kepada pasien dengan perasaan dan tindakan yang menjaga privacy pasien (Keliat, 1996). Sebanyak $63,3 \%$ responden telah memberikan kesempatan bertanya pada pasien sebelum tindakan. Secara keseluruhan (100\%) responden telah mengukur tekanan darah, nadi, dan gula darah dengan glucometri. Kadar gula harus dipantau secara berkala. Dalam melakukan tindakan pada fase kerja ini perawat memastikan atau observasi gula darah, tekanan darah, dan nadi untuk mengontrol adanya komplikasi pada pasien (Hartini, 2009). Sebanyak 53,3\% atau lebih dari separo responden menginformasikan perubahan gaya hidup. Pengobatan diabetes memerlukan waktu yang lama, teratur, terjadwal, dan perlu disiplin serta dengan mengubah pola hidup gaya hidup (Hartini, 2009). Sebanyak $70 \%$ atau lebih dari separo responden telah menjelaskan makan/diet. Hal ini sesuai dengan teori bahwa pasien harus mampu belajar mandiri dengan memperkirakan asupan makan seimbang sehingga asupan yang dikonsumsi benar-benar mencukupi kebutuhannya, yaitu jumlah, jenis, dan jadwal. Dengan mengulang tentang edukasi diet pada fase kerja pasien menjadi ingat bahwa diet $3 \mathrm{~J}$ yaitu Jadual, Jumlah, dan Jenis sangat penting pada pasien DM 9 (Rafikasari, 2016). Sebanyak 66,7 \% atau lebih dari separo responden menganjurkan olah raga. Olah raga atau latihan jasmani adalah pilar pengendalian diabetes dan berat badan, gula yang tinggi juga 
disebabkan oleh resistensi insulin yang dicetuskan oleh kegemukan (Hartini, 2009). Sebanyak 96,7\% atau sebagian besar responden menganjurkan pengobatan rutin. Kepatuhan pengobatan rutin dengan dosis dan waktu yang tepat dan pasien wajib konsultasi kepada dokter ahli (Rafikasari, 2016). Pada pelaksanaan tindakan edukasi fase kerja ini perawat selalu memberi pesan pada pasien untuk kontrol serta pengobatan rutin. Sebanyak $86,7 \%$ atau sebagian besar responden menganjurkan pemantauan mandiri. Pemantauan gula darah wajib dilakukan secara rutin dengan tujuan untuk mengetahui efektifitas dari diet, aktivitas dan pengobatan, serta untuk mengetahui secara dini adanya komplikasi (Rafikasari, 2016). Dalam edukasi ini perawat memberi pesan terhadap pasien bahwa pemantauan gula darah mandiri dapat dilakukan kapan saja, sebelum makan, sesudah makan atau saat muncul gejala lemas atau gula darah turun.

Dari hasil penelitian yang terdiri dari 30 responden, pada fase terminasi didapatkan sebagian besar reponden $(90 \%)$ membereskan alat dan cuci tangan. Seluruh responden $(100 \%)$ tanggap terhadap respon pasien, teliti, ramah, sabar, cekatan terhadap tindakan yang dilakukan pada saat melakukan edukasi. Pemberian edukasi oleh perawat dapat diterima oleh para pasiennya harus memperhatikan beberapa aspek yang antara lain mau menanggapi pertanyaan pasien (emphaty) dan memberikan jawaban yang dapat memuaskan pasien (responsiveness) (Jasmani, 2016). Dalam hal ini untuk mencegah terjadinya kesalahan yang dapat membahayakan keselamatan pasien. 
Tabel 2

Distribusi Frekuensi Pelaksanaan Edukasi Pengendalian Gula Darah pada Pasien Diabetes Mellitus Tipe 2 di Rumah Sakit Panti Rapih Yogyakarta

\begin{tabular}{|c|l|c|c|c|}
\hline No. & $\begin{array}{l}\text { Pelaksanaan Edukasi Terhadap Pengendalian Gula } \\
\text { Darah pada Pasien Diabetes Mellitus Tipe 2 Oleh } \\
\text { Perawat di Rawat Jalan Rumah Sakit Panti Rapih } \\
\text { Yogyakarta }\end{array}$ & Jumlah & $\%$ \\
\hline 1. & Baik & 25 & 83,3 \\
\hline 2. & Cukup & 5 & 16,7 \\
\hline 3. & Kurang Jumlah & 0 & 0 \\
\hline \multicolumn{2}{|r|}{} & 30 & 100 \\
\hline
\end{tabular}

Berdasarkan tabel 2, hasil penelitian yang terdiri dari 30 responden, didapatkan sebagian besar $(83,3 \%)$ telah melakukan edukasi terhadap pengendalian gula darah pada pasien Diabetes Mellitus Tipe 2 dengan baik yang berarti telah melakukan prosedur sesuai dengan standar operasional prosedur. Kewajiban perawatlah yang harus membuat pasien mengerti, memberikan edukasi atau penyuluhan tentang diabetes merupakan tugas perawat. Melalui edukasi diabetes pasien dapat mengetahui dan mengerti apa itu diabetes, masalah yang harus dihadapi, mengapa penyakit ini perlu dikendalikan secepatnya dan tentunya penyuluhan harus dilakukan berulang-ulang (Hartini, 2009).

\section{KESIMPULAN DAN SARAN}

\section{Kesimpulan}

Berdasarkan hasil penelitian dan pembahasan yang telah diuraikan dapat disimpulkan sebagai berikut:

1. Pelaksanaan edukasi pengendalian gula darah pada pasien Diabetes Mellitus tipe 2 berdasarkan fase prainteraksi.

Sebanyak 30 responden $(100 \%)$ atau seluruh responden mengecek catatan keperawatan pasien dan menyiapkan leaflet DM dari Rumah Sakit Panti Rapih.

2. Pelaksanaan edukasi pengendalian gula darah pada pasien Diabetes Mellitus tipe 2 berdasarkan fase orientasi 
Pelaksanaan Edukasi Pengendalian Gula Darah Pasien Diabetes Melitus Tipe 2 di Rumah Sakit Panti Rapih Yogyakarta

Sebanyak 30 responden (100\%) atau seluruh responden melakukan indentifikasi dengan menanyakan nama dan tanggal lahir pasien. Sebanyak 28 responden $(93,3 \%)$ atau sebagian besar responden memberi salam dan menyebutkan nama pasien.

Sebanyak 11 responden $(36,7 \%)$ atau kurang dari separo responden memperkenalkan nama. Sebanyak 17 responden $(56,7 \%)$ atau lebih dari separo responden menjelaskan tindakan penyuluhan yang akan dilakukan. Sebanyak 22 responden (73,3\%) atau lebih dari separo menjelaskan peran perawat dan peran pasien yang harus dilakukan.

3. Pelaksanaan edukasi pengendalian gula darah pada pasien Diabetes Mellitus tipe 2 berdasarkan fase kerja.

Sebanyak 30 responden (100\%) atau seluruh responden memastikan privacy pasien terjaga. Sebanyak 30 responden (100\%) atau seluruh responden melakukan pengkajian pasien.
Sebanyak 19 responden $(63,3 \%)$ atau lebih dari separo responden memberikan kesempatan bertanya sebelum tindakan observasi. Sebanyak 30 responden (100\%) atau seluruh responden melakukan pengukuran darah, nadi, dan glucometri. Sebanyak 16 responden $(53,3 \%)$ atau lebih dari separo responden menginformasikan perubahan gaya hidup. Sebanyak 21 responden $(70 \%)$ atau lebih dari separo responden menjelaskan pengaturan makan/diet. Sebanyak 20 responden $(66,7 \%)$ atau lebih dari separo menganjurkan pasien untuk olah raga. Sebanyak 29 responden $(96,7 \%)$ atau sebagian besar menganjurkan pasien pengobatan rutin. Sebanyak 26 responden $(86,7 \%)$ atau lebih dari separo responden menganjurkan pemantauan mandiri.

4. Pelaksanaan edukasi pengendalian gula darah pada pasien Diabetes Mellitus tipe 2 berdasarkan fase terminasi.

Sebanyak 27 responden (90\%) atau sebagian besar 
responden membereskan alat-alat dan mencuci tangan. Sebanyak 30 responden $(100 \%)$ atau seluruh responden mencatat dokumentasi di rekam medis, tanggap terhadap pasien, bersikap teliti, ramah, sabar, dan cekatan dalam memberikan edukasi.

5. Pelaksanaan edukasi pengendalian gula darah pada pasien Diabetes Mellitus tipe 2.

Sebanyak 25 responden $(83,3 \%)$ atau sebagian besar responden dalam kriteria baik. Sebanyak 5 responden $(16,7 \%)$ atau sebagian kecil responden dalam kriteria cukup dan sebanyak 0 responden $(0 \%)$ atau tidak ada responden dalam kriteria kurang saat melaksanakan prosedur edukasi terhadap pengendalian gula darah pada pasien DM tipe 2 .

\section{Saran}

1. Bagi Perawat Rawat Jalan RS Panti Rapih

a. Sebaiknya memperkenalkan nama dalam melakukan tindakan keperawatan. Dalam edukasi dibutuhkan kepercayaan antara pasien dengan pemberi edukasi.

b. Sebaiknya menjelaskan tujuan tindakan penyuluhan yang akan dilakukan kepada pasien.

c. Sebaiknya menginformasikan perubahan gaya hidup. Hal ini perlu bagi pasien pengobatan diabetes yang memerlukan waktu lama, pengobatan harus teratur, terjadwal, dan perlu disiplin serta dengan mengubah pola hidup/gaya hidup supaya pasien selalu teringat akan gaya hidup yang sehat bagi penderita Diabetes Mellitus tipe 2.

2. Bagi Rumah Sakit

Perlu meningkatkan pengetahuan perawat yang diberikan kewenangan dalam memberikan penyuluhan kepada pasien menggunakan SOP yang telah ditinjau kembali.

3. Bagi Penelitian Selanjutnya

Penelitian ini dapat dilanjutkan dengan topik efektivitas edukasi pengendalian gula darah terhadap pola hidup penderita Diabetes Melitus Tipe 2. 
Pelaksanaan Edukasi Pengendalian Gula Darah Pasien Diabetes Melitus Tipe 2 di Rumah Sakit Panti Rapih Yogyakarta

\section{DAFTAR PUSTAKA}

Hartini, S. (2009). Diabetes? Siapa takut. Penerbit Qanita PT Mizan Pustaka. Bandung.

Infodatin. (2018). Hari Diabetes Sedunia 2018. Pusat Data Dan Informasi Kemenkes RI. ISSN 2442-7659.

Jasmani, Rihiantoro, T. (2016). Edukasi Dan Kadar Glukosa Darah Pada Pasien Diabetes. Jurnal Keperawatan. Volume XII. No. 1. April 2016.

Keliat, B. A. (1996). Hubungan Terapeutik Perawat Klien. Penerbit Buku Kedokteran EGC. Jakarta.

Kusuma, C. (2013). Hubungan komunikasi terapeutik perawat dalam tindakan keperawatan dengan tingkat kepuasan pasien di bangsal penyakit dalam RSUD Wates. Skripsi. STIKes. A. Yani. Yogyakarta.
Rafikasari, D. (2016). Jalankan 5 Pilar, Bantu Penderita Diabetes Hidup Normal, https://lifestyle.sindonews.co $\mathrm{m} / \mathrm{read} / 1155109 / 155 /$ jalanka n-5-pilar-bantu-penderitadiabetes-hidup-normal.

Soegondo, S., dkk. (2013). Penatalaksanaan Diabetes Melitus. Penerbit FKUI. Jakarta.

Sutedjo, A. Y. (2010). 5 Strategi Penderita Diabetes Mellitus Berusia Panjang. Penerbit Kanisius. Yogyakarta. 